\title{
ERRATA
}

\section{Erratum: Chipping away at the chip bias: RNA degradation in microarray analysis}

H Auer, S Lyianarachchi, D Newsom, M I Klisovic, G Marcucci \& K Kornacker Nat. Genet. 35, 292-293 (2003).

The name of the fifth author was spelled incorrectly. The correct spelling is "Guido Marcucci".

Erratum: Gene-culture coevolution between cattle milk protein genes and human lactase genes

A Beja-Pereira, G Luikart, P R England, D G Bradley, O C Jann, G Bertorelle, A T Chamberlain, T P Nunes, S Metodiev, N Ferrand \& G Erhardt

Nat. Genet. 35, 311-313 (2003).

The paper mistakenly contained a reference to Supplementary Figure 1 online; there is no such figure. 